\title{
Interactions among biological control agents on waterhyacinth: impacts of herbivory on the oviposition and development of Megamelus scutellaris
}

\author{
A. B. C. Goode ${ }^{a}$, B. K. Knowles ${ }^{a}$, P. W. Tipping ${ }^{a}$, J. R. Foley ${ }^{b}$ and L. A. Gettys \\ ${ }^{a}$ USDA-ARS Invasive Plant Research Laboratory (IPRL), Ft. Lauderdale, FL, USA; ${ }^{\circ}$ Department of Entomology, \\ Virginia Polytechnic Institute and State University, Blacksburg, VA, USA; 'University of Florida Fort Lauderdale \\ Research and Education Center, Ft. Lauderdale, FL, USA
}

\begin{abstract}
Multiple biological control agents have been developed and released to increase control and reduce treatment costs of Pontederia (Eichhornia) crassipes in Florida. Although two species of weevil (Neochetina eichhorniae and Neochetina bruchi) and the planthopper (Megamelus scutellaris) utilise $P$. crassipes for feeding and reproduction, little is known about their interactions including any negative interactions that might reduce their individual or overall effectiveness in suppressing the plant. Megamelus scutellaris was provided with the choice of weevil-damaged or undamaged plants and allowed to oviposit. Plants were then monitored individually for nymph emergence to determine the plant preference for adults. There were no differences in $F_{1}$ emergence numbers among the treatments indicating that in this specific situation the potential for negative interactions between Neochetina spp. and $M$. scutellaris is minimal. Additional studies are required to quantify the potential for other types of interactions among these biological control agents.
\end{abstract}

\section{ARTICLE HISTORY}

Received 5 March 2020

Accepted 30 July 2020

\section{KEYWORDS}

Biological control; Megamelus scutellaris; Neochetina bruchi; Neochetina eichhorniae; Pontederia (Eichhornia) crassipes; niche partitioning

\section{Introduction}

In Florida, Pontederia (Eichhornia) crassipes (Mart.) Solms is an invasive aquatic plant that affects $47 \%$ of waterways (FFWCC, 2017). It grows year-round in the sub-tropical regions of the state disrupting native habitats and blocking flood control structures and navigational channels (Center, 1987), and thus requires continual management (Rivers and Harbors Appropriation Act of 1899 [33 U.S.C. 403; Chapter 425, March 3, 1899; 30 Stat. 1151]). Maintenance control using herbicides has been the primary management tactic employed for this plant since the 1950s. This approach requires consistent public support to fund but recently this support has eroded in favour of physical methods like harvesters (Williams, 2019).

Biological control agents were developed in the 1960s and 1970s for use on $P$. crassipes to provide more sustainable control and reduce treatment costs (Harley, 1990). Four nonnative insect agents were discovered, developed, and deployed in Florida: Neochetina 
eichhorniae Warner (Coleoptera: Curculionidae), Neochetina bruchi Hustache (Coleoptera: Curculionidae), Niphograpta albiguttalis (Warren) (Lepidoptera: Crambidae) and, most recently, Megamelus scutellaris (Berg) (Hemiptera: Delphacidae) (Center, 1982; Center, 1984; Tipping et al., 2014b). Herbivory by the Neochetina spp. weevils and M. scutellaris has been shown to increase the effectiveness of herbicide treatments and slow regrowth of the plants following treatment (Tipping et al., 2017). Currently, N. albiguttalis is found mainly along expanding edges of mats, both weevil species are ubiquitous (Tipping et al., 2014a), and M. scutellaris populations are still relatively low but expanding outward from release sites (Tipping et al., 2014b).

The population dynamics of biological control agents are influenced by a myriad of factors including genotype or climate matching, attack by parasitoids and predators, and interspecific competition from other herbivores (McFadyen, 1998). The Florida population of M. scutellaris consists of two genotypes collected from two climatically different areas of South America (Foley et al., 2016) increasing the chances of establishment, particularly regarding climate matching.

Although native parasitoids are known to utilise $M$. scutellaris in its extant range, overall parasitism is relatively low (Minteer et al. 2016). Tipping et al. (2020) found no evidence of apparent competition between M. scutellaris and M. davisi, a native planthopper with the shared native parasitoid Kalopolynema ema (Schauff and Grissell) (Hymenoptera: Mymaridae) in Florida. Although parasitism has never been documented as the cause of a biological control agent species failing to establish, it has been shown to reduce their effectiveness (Paynter et al., 2010).

Competition from Neochetina spp. may be another factor that influences M. scutellaris population dynamics in Florida and elsewhere. When introducing multiple insect species to control an invasive plant, agents with different feeding niches are generally chosen in order to reduce the potential for competition that would lead to a reduction in the suppression of the target weed. Releasing multiple agents in this way can increase the success of a biological control programme through the process of niche partitioning (Denoth et al., 2002). While one or both Neochetina weevils and M. scutellaris have been released in other countries (Hill \& Coetzee, 2017), little is known about their interactions.

Since Megamelus scutellaris was released in Florida to control P. crassipes in 2010 it has established populations in many areas but has not dispersed widely (Tipping et al., 2014b). One potential cause of this is an antagonistic interaction with $N$. eichhorniae and N. bruchi, both initially released in Florida in the 1970s (Center, 1982) and now found across the state wherever there is P. crassipes (Tipping et al., 2014a). While all three species are found together and feed on different areas of the leaf, there is an overlapping area of the plant used by all species (DeLoach \& Cordo, 1976; Sosa et al., 2004). Megamelus scutellaris oviposits primarily on or near the isthmus between the petiole and lamina (Sosa et al., 2004), an area that is often heavily damaged by Neochetina spp. feeding, thus posing a potential conflict whereby Neochetina spp feeding may interfere with M. scutellaris oviposition and egg development. Neochetina spp. are ubiquitous in Florida and in South America (Bennett \& Zwolfer, 1968; Tipping et al., 2014a) and thus the availability of undamaged plants would probably be low in either range. In Florida, it is rare to see P. crassipes without any Neochetina spp. feeding damage (pers. obs.). The objective of this experiment was 
to determine if Neochetina spp. herbivory affected $M$. scutellaris choice of plants (damaged or undamaged) for oviposition and $F_{1}$ nymph production.

\section{Methods}

All $P$. crassipes test plants were initially grown in isolation with no herbivory before being placed into separate plastic $4.2 \mathrm{~L}$ testing cages $(21.6 \times 11.4 \times 28.3 \mathrm{~cm}$ with $8 \times$ $6.5 \mathrm{~cm}$ area of the water-tight lid screened with fine mesh) containing $0.5 \mathrm{~L}$ of fertilised water (Osmocote Plus 15-9-12 [ICL Fertilizers, Dublin, Ohio; 0.31 g per liter]). Two trials were conducted at the USDA-ARS Invasive Plant Research Laboratory (IPRL) in Fort Lauderdale, FL, USA: the first during August-September 2019 and the second during October-November 2019. The first trial had three treatments replicated ten times (Table 1) with each treatment containing two $P$. crassipes plants in one $4.2 \mathrm{~L}$ cage. The treatments provided $M$. scutellaris adults a choice to oviposit in either of two plants of the same type (both Neochetina spp. damaged or both undamaged by Neochetina spp. ['clean']) or between a damaged and a clean plant. The second trial was identical to the first, with the addition of a treatment of two damaged plants that were not exposed to M. scutellaris. This treatment was monitored to determine if Neochetina spp. herbivory alone caused mortality to $P$. crassipes over the duration of the experiment. Five clean plants were also pruned down to a single leaf with scissors as close to the central bud as possible and kept in the same manner as above and monitored to determine if pruning alone caused mortality to $P$. crassipes over the duration of the experiment. Test cages were kept in the lab, with ambient humidity and temperature (range: 23$30.5^{\circ} \mathrm{C}$, average: $24.5^{\circ} \mathrm{C}$ ) and a $12: 12 \mathrm{~L}: \mathrm{D}$ photoperiod.

To produce damaged plants, Neochetina spp. were collected from outdoor wild colonies and held without food for 24 hours. In this experiment, the weevils used were $51.5 \%$ N. eichhorniae and $48.5 \%$ N. bruchi. Four individuals were selected without accounting for sex or species, placed on each plant, allowed to feed for 48 hours, and then removed. The most damaged leaf was left on the plant and all others were removed with scissors as close to the central bud as possible. Leaves were pruned in order to control for uneven damage within a plant's leaves and to ensure accuracy of recording from which leaf a nymph emerged. Percent defoliation of the single leaf was assessed visually by estimating the area of feeding damage on the adaxial leaf surface to the nearest $10 \%$. Clean plants also had all but one leaf pruned in the same fashion, and attempts were made to select leaves of relatively equal size to those on the damaged plant.

Immediately following exposure to Neochetina spp. and pruning, four (2 o / 2 ๙), 1-2 week old, captive reared, brachypterous $M$. scutellaris were anaesthetized with $\mathrm{CO}_{2}$ and placed into a weigh boat floating between the two plants in each cage. They were monitored for an hour afterwards to ensure recovery, which generally occurred within minutes of release, and the weigh boat was left in place until the conclusion of this part of the experiment to reduce disturbance. From previous experiments, it has been shown that females tend to oviposit immediately after release, then disperse (Goode et al., 2019). All M. scutellaris were removed from all insect treatments after 72 hours and each of the two plants was moved to separate cages and monitored daily for 21 days for 
emerging nymphs which were counted and removed. Monitoring was discontinued if no nymphs were found on two consecutive days. Nymphs were used as a proxy for oviposition because the process of counting eggs embedded in plant tissue is destructive and would have influenced the results.

The statistical programme $\mathrm{R}$ ( $\mathrm{R}$ version 3.6.1; R Core Team, 2019) was used to check nymph emergence data for normality and paired $t$-tests were used to determine differences in emergence between plants within each treatment. Wilcoxon rank sum tests were used to determine differences in defoliation in the 'choice' and the damaged 'no-choice' treatments. An ANOVA was used to examine differences in emergence between plants among the treatments. Additionally, a logistic regression model was used to determine if percent defoliation influenced plant mortality.

\section{Results}

There were no significant differences in nymph emergence between plants within any of the treatments (Table 1) and there was no significant difference in nymph emergence among the treatments $\left(F_{2,65}=0.63, p=0.54, \eta^{2}=0.02\right)$. Plants did differ in defoliation in the 'Choice' treatment $(W=390, p \ll 0.001$, Table 2$)$, but not in the damaged 'NoChoice' treatment ( $W=430, p=0.76$ ). Plant mortality was negatively influenced by the amount of defoliation (coefficient estimate $=0.15, \mathrm{SE}=0.03, z=4.645, p<0.0001$ ), with nearly twice as many plants with defoliation above $10 \%$ dying compared to surviving the experiment (Table 2).

Table 1. 'Choice' and 'No Choice' paired $t$-test results. Plants were compared within each test tank to determine differences in oviposition. 'Choice' treatments contained different plant types while 'No Choice' treatments contained plants of the same type.

\begin{tabular}{lllc}
\hline Treatment & $t$ & $d f$ & $p$ \\
\hline No Choice (Clean) & -0.38 & 17 & 0.71 \\
No Choice (Damaged) & -0.20 & 29 & 0.84 \\
Choice & 0.85 & 19 & 0.41 \\
\hline
\end{tabular}

Table 2. Means $\pm S D$ of defoliation, nymph emergence, and plant mortality. 'Choice' treatments contained different plant types while 'No Choice' treatments contained plants of the same type. Some replications were lost due to female $M$. scutellaris accidentally not being removed prior to beginning of the experiment.

\begin{tabular}{|c|c|c|c|c|c|c|c|c|}
\hline & \multirow[b]{2}{*}{ Treatment } & \multirow[b]{2}{*}{ Plant type } & \multirow[b]{2}{*}{$N$} & \multicolumn{2}{|c|}{ \% Defoliation } & \multicolumn{2}{|c|}{ Nymphs Emerged } & \multirow[b]{2}{*}{ Plant Mortality } \\
\hline & & & & Mean & SD & Mean & SD & \\
\hline \multirow[t]{4}{*}{ Trial 1} & Choice & Damaged & 9 & 5.56 & 2.83 & 12.33 & 8.73 & 0 \\
\hline & & Clean & 10 & 0 & 0 & 11.1 & 5.49 & 0 \\
\hline & No Choice & Clean & 16 & 0 & 0 & 13.75 & 12.61 & $6.25 \%$ \\
\hline & No Choice & Damaged & 40 & 12.38 & 10.06 & 11 & 11.08 & $27.50 \%$ \\
\hline \multirow[t]{5}{*}{ Trial 2} & Control & Damaged & 20 & 13.75 & 9.73 & 0 & 0 & $15 \%$ \\
\hline & Choice & Damaged & 10 & 12.5 & 10.06 & 45.1 & 33.13 & $60 \%$ \\
\hline & & Clean & 10 & 0 & 0 & 30.2 & 32.99 & $0 \%$ \\
\hline & No Choice & Clean & 20 & 0 & 0 & 43.9 & 19.60 & $0 \%$ \\
\hline & No Choice & Damaged & 20 & 15 & 10.12 & 36.4 & 25.54 & $20 \%$ \\
\hline
\end{tabular}




\section{Discussion}

While M. scutellaris has successfully established in Florida, its density at some locations remains low (Tipping et al., 2014b). Other biological control agents have been released against $P$. crassipes in Florida and have established and dispersed (Center, 1982). Neochetina spp. weevils are pervasive (Tipping et al., 2014a) and feed on the same areas of the plant that M. scutellaris generally oviposit (DeLoach \& Cordo, 1976; Sosa et al., 2004). This study showed that prior herbivory by Neochetina spp. does not influence plant choice for oviposition by M. scutellaris, as indicated by similar numbers of nymphs emerging from both plant types in the 'Choice' treatment, even though there were significantly different amounts of defoliation between the two types of plants. This experiment did not address location of $M$. scutellaris oviposition on the $P$. crassipes plant, which may be influenced by plant tissue damage and interactions with Neochetina spp. Additionally, plants exposed to both insects had a higher mortality rate than those exposed to either type of insect individually. This indicates that there is at least an additive effect of the biological control insects on $P$. crassipes mortality, although these results should be interpreted with caution because to the small sample size in this experiment.

The present experiment also did not examine the potential influence of herbivory damage from Neochina spp. following oviposition by M. scutellaris or the effects of Neochetina spp. larvae causing additional plant deterioration. This study explored one potential antagonistic interaction in a system where there may be many including additive, synergistic, and other antagonistic interactions. Despite this, the long-term presence of all three species on plants at release locations for $M$. scutellaris suggests that some degree of niche partitioning is present.

\section{Acknowledgements}

The authors thank S. Luz Salinas and Laurent Duverglas at the Invasive Plant Research Laboratory for their assistance with the experiment. Mention of trade names or commercial products in this publication is solely for the purpose of providing specific information and does not imply recommendation or endorsement by the U.S. Department of Agriculture (USDA).

\section{Disclosure statement}

No potential conflict of interest was reported by the author(s).

\section{ORCID}

A. B. C. Goode (D http://orcid.org/0000-0001-6515-3954

\section{References}

Bennett, F. D., \& Zwolfer, H. (1968). Exploration for natural enemies of the water hyacinth in northern South America and Trinidad. Hyacinth Control Journal, 7, 44-52.

Center, T. D. (1982). The waterhyacinth weevils, Neochetina eichhorniae and N. bruchi. Aquatics, 4 (2), 8-19.

Center, T. D. (1984). Dispersal and variation in infestation intensities of waterhyacinth moth, Sameodes albiguttalis (Lepidoptera: Pyralidae) population in peninsular Florida. Environmental Entomology, 13(2), 482-491. https://doi.org/10.1093/ee/13.2.482 
Center, T. D. (1987). Insects, mites, and plant pathogens as agents of waterhyacinth (Eichhornia crassipes (Mart.) Solms) leaf and ramet mortality. Lake and Reservoir Management, 3(1), 285293. https://doi.org/10.1080/07438148709354784

DeLoach, C. J., \& Cordo, H. A. (1976). Ecological studies of Neochetina bruchi and N. eichhorniae on waterhyacinth in Argentina. Journal of Aquatic Plant Management, 14, 53-59.

Denoth, M., Frid, L., \& Myers, J. H. (2002). Multiple agents in biological control: Improving the odds? Biological Control, 24(1), 20-30. https://doi.org/10.1016/S1049-9644(02)00002-6

Florida Fish \& Wildlife Conservation Commission (FFWCC). (2017). Status of the aquatic plant maintenance program in Florida Public Waters, annual report - Fiscal year 2016-2017.

Foley, J. R., Minteer, C., \& Tipping, P. W. (2016). Differences in seasonal variation between two biotypes of Megamelus scutellaris (Hemiptera: Delphacidae), a biological control agent for Eichhornia crassipes (Pontederiaceae) in Florida. Florida Entomologist, 99(3), 569-571. https:// doi.org/10.1653/024.099.0340

Goode, A. B., Minteer, C. R., Tipping, P. W., Knowles, B. K., Valmonte, R. J., Foley, J. R., \& Gettys, L. A. (2019). Small-scale dispersal of a biological control agent-Implications for more effective releases. Biological Control, 132, 89-94. https://doi.org/10.1016/j.biocontrol.2019.01.016

Harley, K. L. S. (1990). The role of biological control in the management of water hyacinth, Eichhornia crassipes. Biocontrol News and Information, 11, 11-22.

Hill, M. P., \& Coetzee, J. (2017). The biological control of aquatic weeds in South Africa: Current status and future challenges. Bothalia-African Biodiversity \& Conservation, 47(2), 1-12. https:// doi.org/10.4102/abc.v47i2.2152

McFadyen, R. E. C. (1998). Biological control of weeds. Annual Review of Entomology, 43(1), 369393. https://doi.org/10.1146/annurev.ento.43.1.369

Minteer, C. R., Tipping, P. W., Knowles, B. K., Valmonte, R. J., \& Foley, J. R. (2016). Utilization of an introduced weed biological control agent, Megamelus scutellaris (Hemiptera: Delphacidae), by a native parasitoid. Florida Entomologist, 99(3), 576-577. https://www.jstor.org/stable/ 24891112

Paynter, Q., Fowler, S. V., Hugh Gourlay, A., Groenteman, R., Peterson, P. G., Smith, L., \& Winks, C. J. (2010). Predicting parasitoid accumulation on biological control agents of weeds. Journal of Applied Ecology, 47(3), 575-582. https://doi.org/10.1111/j.1365-2664.2010.01810.x

R Core Team. (2019). R: A language and environment for statistical computing. R Foundation for Statistical Computing. https://www.R-project.org/

Sosa, A. J., Remes Lenicov, A. M., Mariani, R., \& Cordo, H. A. (2004). Redescription of Megamelus scutellaris Berg (Hemiptera: Delphacidae), a candidate for biological control of water hyacinth. Annals of the Entomological Society of America, 97(2), 271-275. https://doi.org/10.1093/aesa/97. 2.271

Tipping, P. W., Gettys, L. A., Minteer, C. R., Foley, J. R., \& Sardes, S. N. (2017). Herbivory by biological control agents improves herbicidal control of waterhyacinth (Eichhornia crassipes). Invasive Plant Science and Management, 10(3), 271-276. https://doi.org/10.1017/inp.2017.30

Tipping, P. W., Martin, M. R., Pokorny, E. N., Nimmo, K. R., Fitzgerald, D. L., Dray Jr, F. A., \& Center, T. D. (2014a). Current levels of suppression of waterhyacinth in Florida USA by classical biological control agents. Biological Control, 71, 65-69. https://doi.org/10.1016/j.biocontrol.2014. 01.008

Tipping, P. W., Smith, M. C., Lake, E. C., Minteer, C. R., Goode, A. B. C., Foley, J. R., \& Gettys, L. A. (2020). Classical biological control and apparent competition: Evaluating a waterhyacinth invaded community module. Journal of Applied Ecology, 57(5), 926-935. https://doi.org/10. 1111/1365-2664.13593

Tipping, P. W., Sosa, A., Pokorny, E. N., Foley, J., Schmitz, D. C., Lane, J. S., Rodgers, L., McCloud, L., Livingston-Way, P., Cole, M. S., \& Nichols, G. (2014b). Release and establishment of Megamelus scutellaris (Hemiptera: Delphacidae) on waterhyacinth in Florida. Florida Entomologist, 97(2), 804-806. https://doi.org/10.1653/024.097.0264

Williams, A. B. (2019, February 7). State halts putting herbicide on nuisance water plants while it gathers public input. https://www.news-press.com/story/tech/science/environment/2019/02/07/ state-halts-putting-herbicide-nuisance-water-plants-while-gathers-public-input/2746290002/ 